\title{
THE QUALITY OF RABBIT HIDE TANNED BY MANGROVE (Rhizopora mucronata)
}

\section{Wehandaka PANCAPALAGA*, Suyatno NITIHARJO}

Faculty of Agriculture and Animal Husbandry, University of Muhammadiyah Malang, Indonesia, Jalan Raya Tlogomas 246

Malang, email: pancapalaga1966@gmail.com

\section{THE QUALITY OF RABBIT HIDE TANNED BY MANGROVE (Rhizopora mucronata)}

ABSTRACT. Mangrove stem (Rhizopora mucronata) contains a tannin compound which has potential as tanning material as well as tanner leather coloring. Meanwhile, the public uses more tannin from mimosa tannin and has not optimized the use of mangrove tannins. This study aimed to determine the quality of rabbit hide tanned from mangrove tannin and mimosa tannin. The material used was Rex rabbit hide of 1-year age cut. The research method used a completely random design (CRD) experiment. The treatment ratio of mangrove stem tannin and tannin mimosa concentration were $0: 30 \%, 10: 20 \%, 20: 10 \%$ and 30\%:0. The parameters measured by chemical properties consist of: degree of tanning, moisture, ash and tannin bound to the skin. Physical properties consisted of: tensile strength, elongation and sewing strength. The results showed that the use of mangrove tannin and mimosa tannin for tanning ratios had no significant effect $(P>0.05)$ on the level of tanning, moisture, ash, and tannin that were bound to tanned skin, tensile strength, elongation and sewing strength. The results showed that the quality of tanned hide had a tanning degree of $62.31 \%, 13.32 \%$ moisture content, $1.57 \%$ ash content, and $25.14 \%$ tannin content. The physical quality of tensile strength was $356.35 \mathrm{~N} / \mathrm{cm}$, elongation was $29.80 \%$ and sewing strength is $84.41 \mathrm{Kg} / \mathrm{cm}$. The results of the quality of this tanned hide had fulfilled SNI 06-6121-1999 of leather goods. The conclusion was that tannin extract from mangroves can be used as vegetable tanning agent, with the same quality as mimosa tanning agent.

KEY WORDS: mangrove tannin, mimosa tannin, rabbit hide, quality of hide

CALITATEA PIELII DE IEPURE TĂBĂCITĂ CU MANGROVE (Rhizopora mucronata)

REZUMAT. Tulpina de mangrove (Rhizopora mucronata) conţine un tanin care are potenţial ca material de tăbăcire, precum şi de colorare a pielii tăbăcite. Pe de altă parte, se foloseşte mai mult tanin din mimosa, iar utilizarea taninului din mangrove nu este optimizată. Acest studiu are scopul de a determina calitatea pielii de iepure tăbăcite cu tanin din mangrove şi tanin din mimosa. S-a utilizat ca material o piele de iepure Rex, la vârsta de 1 an. Metoda de cercetare a presupus desfăşurarea unui experiment cu design complet aleatoriu (CRD). Rapoartele de concentraţii de tanin din tulpină de mangrove şi tanin din mimosa au fost de 0:30\%, 10:20\%, 20:10\% şi 30\%:0. Parametrii măsuraţi prin proprietăţile chimice au reprezentat: gradul de tăbăcire, umiditate, cenuşă şi taninul legat de piele. Proprietăţile fizice au constat în: rezistenţă la tracţiune, alungire şi rezistenţă la coasere. Rezultatele au arătat că utilizarea taninului din mangrove şi a taninului din mimosa în raporturile de concentraţii menționate nu a avut niciun efect semnificativ $(P>0,05)$ asupra valorilor gradului de tăbăcire, umidităţii, cenuşii şi taninului legat de pielea tăbăcită, rezistenţei la tracţiune, alungirii şi rezistenţei la coasere. Rezultatele au arătat că pielea tăbăcită a avut un grad de tăbăcire de $62,31 \%$, umiditate $13,32 \%$, conţinut de cenuşă 1,57\% şi conţinut de tanin $25,14 \%$. În ceea ce priveşte proprietăţile fizice, rezistenţa la tracţiune a fost de $356,35 \mathrm{~N} / \mathrm{cm}$, alungirea de $29,80 \%$ şi rezistenţa la coasere de $84,41 \mathrm{~kg} / \mathrm{cm}$. Rezultatele au arătat că nivelul de calitate a pielii tăbăcite a îndeplinit standardele indicate în SNI 06-6121-1999 referitor la articolele din piele. Concluzia a fost că extractul de tanin din mangrove poate fi folosit ca agent de tăbăcire vegetal, obţinând aceeaşi calitate ca în cazul utilizării agentului de tăbăcire din mimosa.

CUVINTE CHEIE: tanin din mangrove, tanin din mimosa, piele de iepure, calitatea pielii

\section{LA QUALITÉ DE LA PEAU DE LAPIN TANNÉE PAR MANGROVE (Rhizopora mucronata)}

RÉSUMÉ. La tige de la mangrove (Rhizopora mucronata) contient un tanin au potentiel tannant, ainsi qu'une coloration de la peau tannée. D'autre part, on utilise davantage de tanin de mimosa, tandis que l'utilisation de tanin de mangrove n'est pas optimisée. Cette étude vise à déterminer la qualité de la peau de lapin tannée au tanin de mangrove et au tanin de mimosa. Une peau de lapin Rex, âgée de 1 an, a été utilisée comme matériau. Un essai totalement randomisé (CRD) a été utilisé comme méthode de recherche. Les rapports des concentrations de tanin de mangrove et de tanin de mimosa ont été : $0: 30 \%, 10: 20 \%, 20: 10 \%$ et $30 \%: 0$. Les paramètres mesurés par les propriétés chimiques ont représenté : le degré de tannage, l'humidité, les cendres et le tanin lié à la peau. Les propriétés physiques sont les suivantes: la résistance à la traction, l'allongement et la résistance à la couture. Les résultats ont montré que l'utilisation du tanin de mangrove et du tanin de mimosa dans les rapports de concentration mentionnés n'avait pas d'effet significatif $(P>0,05)$ sur les valeurs de tannage, d'humidité, de cendres et de tanins liées au cuir tanné, de résistance à la traction, d'allongement et de résistance à la couture. Les résultats ont montré que le cuir tanné avait un niveau de tannage de $62,31 \%$, une humidité de $13,32 \%$, une teneur en cendres de $1,57 \%$ et une teneur en tanin de $25,14 \%$. En ce qui concerne les propriétés physiques, la résistance à la traction était de $356,35 \mathrm{~N} / \mathrm{cm}$, l'allongement de $29,80 \%$ et la résistance à la couture de $84,41 \mathrm{~kg} / \mathrm{cm}$. Les résultats ont montré que le niveau de qualité du cuir tanné était conforme aux normes indiquées dans le document SNI 06-6121-1999 concernant les articles en cuir. La conclusion a été que l'extrait de tanin de mangrove peut être utilisé comme agent de tannage végétal, à la même qualité que lors de Isutilisation de lıagent de tannage mimosa.

MOTS CLÉS : tanin de mangrove, tanin de mimosa, peau de lapin, qualité de la peau

\footnotetext{
* Correspondence to: Wehandaka PANCAPALAGA, Faculty of Agriculture and Animal Husbandry, University of Muhammadiyah Malang, Indonesia, Jalan Raya Tlogomas 246 Malang, email: pancapalaga1966@gmail.com
} 


\section{INTRODUCTION}

Natural tanning material is more environmentally friendly than synthetic tanning material. Currently the natural tanning material which is widely used is mimosa tannin. Excess use of mimosa tannin can reduce $\mathrm{Cr}(\mathrm{VI})$ when used as a re-tanning [1]. In addition, mimosa tannin as tanning material can increase tensile strength, tensile strength and elongation of the resulting leather [2]. Tanning with mimosa tannin has several properties including tightening and preserving the skin from microbial invasion and can give color to tanning skin as a secondary effect of tanneries [3].

However, one of the weaknesses of the tanning leather with mimosa tannin include low heat stability because the cross-linking between the tanning material and collagen tissue is not strong enough [4]. Besides, tanning with mimosa tannin takes longer and is expensive. For this reason, it is necessary to look for alternative natural ingredients, one of which is tannin taken from mangrove stems (Rhizophora mucronata).

Mangrove (Rhizophora mucronata) in addition to having ecological value also has economic value, the use of its parts such as leaves, fruit, bark, mangrove stems have been widely developed including drugs for hematuria (bleeding in urine), syrups and chips from mangrove fruit, essential oils from leaves as an antidote to malaria mosquitoes [5] and extracts of mangrove plant parts can be used as natural coloring material [6]. However, the use as a tanning material has not been widely studied, even though tannin compounds contained in mangroves have the potential as natural tanning material on leather [7].

According to Rusila et al. [8], mangrove bark (Rhizophora mucronata) is a potential source of tannin as a vegetable tanning which is classified as condensing tannins [9]. Tannin from mangrove bark can be used as an alternative to vegetable tanning because the FTIR spectrum data of mangrove tannin is similar to FTIR spectrum of mimosa [10]. Furthermore, according to Paridah and Musgrave [11], the tannin content in mangrove bark reaches $26 \%$. It was also said that tannin from mangrove stem extracts can be used as vegetable tanning. Unfortunately, the problem is the tannin content in mangroves is not as much as the amount of tannin content from mimosa that is equal to $45 \%$ [12].

This study examined the physical and chemical quality of rabbit hide tanned by mangrove bark compared with mimosa tannin.

\section{EXPERIMENTAL}

\section{Materials and Methods}

\section{Instrument}

The equipment used was tanning drum, manual scale, litmus paper, analytical scale, stainless steel knives, basin, nails, hammer, measuring cups, pencil, scissors, plywood, thermometers, buckets, spatula and foundation boards to dispose meat and fur.

\section{Material}

The material of this study used 12 pieces of rabbit hide $20 \mathrm{~cm} \times 20 \mathrm{~cm}$ obtained from a breeder of rabbits in Malang, while the mangrove tannin extract (Rhizophora Sp.) was extracted by the researcher. Other chemicals used were: Mimosa acacia, lime (4\%), sodium sulfide $(2 \%)$, Za $(3 \%)$, sulfuric acid $(0.75 \%)$, gasoline $(5 \%)$, teepol $(2 \%)$, orophone $(1 \%)$, syntan $(10 \%)$, TRO oil (5\%), and formic acid (1\%).

\section{Research Method}

The study was conducted through experiment with a Completely Random Design (CRD). The parameters measured were the quality of rabbit hide consisting of chemical quality and physical quality. Chemical quality consisted of water content, ash content, tanning degree, tannin content. Physical quality consisted of the leather tensile strength, the elongation, the sewing strength of the leather. The research treatments were the different ratio of mangrove tannins (Rhizophora Sp) and tannin mimosa: (0\%:30\%), (10\%:20\%), (20\%:10\%), (30\%:0\%).

\section{Observation of Chemical and Physical Quality}

The tanned hide was chemically observed, based on Indonesian National Standard (SNI) 06-0463-1989 which included measurement of water, ash, degree of tanning, and tannin contents. Physical testing which included the 
strength of tearing leather, elongation of leather and sewing strength of leather on leather using Indonesian National Standard (SNI) 06-11171989.

\section{Tanning Process}

The tanning process for rabbit using tannins and mimosa tannin is shown in Table 1 below. The process started with washing and finished with retanning.

Table 1: The process of tanning leather using mangrove and mimosa tannin

\begin{tabular}{|c|c|c|c|c|}
\hline Processing Stage & Chemical Material & Concentration (\%) & Time (minute) & $\mathrm{pH}$ \\
\hline Washing & Running water & & 15-minute spin & 7 \\
\hline \multirow[t]{3}{*}{ Liming } & $\mathrm{Na}_{2} \mathrm{~S}\left( \pm 1^{\circ} \mathrm{Be}\right)$ & 2 & 30-minute spin & \multirow[t]{3}{*}{$9-10$} \\
\hline & $\mathrm{Ca}(\mathrm{OH}) 2$ & 5 & 30-minute spin & \\
\hline & Water & 50 & Soaked overnight & \\
\hline Fleshing and unhairing & - & - & & \\
\hline \multirow[t]{2}{*}{ Deliming } & Water & 200 & 30-minute spin & \multirow[t]{2}{*}{$7-8$} \\
\hline & $\mathrm{H}_{2} \mathrm{SO}_{4}$ & 1 & $\begin{array}{l}\text { 30-minute spin } \\
60 \text {-minute spin }\end{array}$ & \\
\hline \multirow[t]{2}{*}{ Degreasing } & Water & 100 & 30-minute spin & \multirow[t]{2}{*}{$7-8$} \\
\hline & Teepol & 2 & 45-minute spin & \\
\hline \multirow[t]{2}{*}{ Bating } & Water below $40^{\circ} \mathrm{C}$ & 100 & 120-minute spin & \multirow[t]{2}{*}{$7-8$} \\
\hline & $\begin{array}{l}\text { Orophon / bating } \\
\text { Agent }\end{array}$ & 1 & & \\
\hline \multirow[t]{5}{*}{ Tanning } & $\begin{array}{l}\text { Water below } 40^{\circ} \mathrm{C} \\
\text { Tannin }\end{array}$ & 100 & 30-minute spin & \multirow[t]{5}{*}{$7-8$} \\
\hline & Mimosa mangrove & 1). $0 \%: 30 \%$ & 120-minute spin & \\
\hline & & 2). $10 \%: 20 \%$ & 120-minute spin & \\
\hline & & 3). $20 \%: 10 \%$ & 120-minute spin & \\
\hline & & 4). $30 \%: 0 \%$ & 120-minute spin & \\
\hline \multirow[t]{2}{*}{ Re-tanning } & Water & 100 & & \multirow[t]{3}{*}{$7-8$} \\
\hline & Syntan & 10 & 30-minute spin & \\
\hline Drying & & & & \\
\hline
\end{tabular}

\section{Mangrove Stem Tannin Extract Process}

The process to do mangrove stem tannin extract was done by the Counter current process, which was done by the fresh mangrove stems were given high concentrated juice, while mangrove stems that were almost out of juice were confronted with fresh water. Tannins contained in mangrove stems are condensed tannins. Condensed tannins for tanning processes are more preferable than the hydrolyzed tannins because they have higher affinity to collagen as the main structural protein of connective tissue.
That is because of their high molecular weight and the number of phenolic groups giving many points to the bonds that occur with the carbonyl group of peptides [14].

\section{RESULT AND DISCUSSION}

The analysis of the quality of rabbit hide tanned by mangrove tannin extract and mimosa tannin with various ratio are presented in Table 2 .

Table 2: Analysis result between chemical and physical quality of tanned rabbit hide

\begin{tabular}{|c|c|c|c|c|c|c|c|}
\hline \multirow[t]{2}{*}{ No } & \multirow[t]{2}{*}{ Variable } & \multicolumn{5}{|c|}{ Ratio mangrove tannin: mimosa tannin } & \multirow[b]{2}{*}{ SNI 06-6121-1999 } \\
\hline & & Unit & $0 \%: 30 \%$ & $10 \%: 20 \%$ & $20 \%: 10 \%$ & $30 \%: 0 \%$ & \\
\hline 1. & Degree of tanning & $\%$ & $62.31^{\mathrm{a}}$ & $54.39^{a}$ & $53.81^{a}$ & $58.69^{a}$ & Minimum at 25 \\
\hline 2. & Water content & $\%$ & $13.32^{\mathrm{a}}$ & $12.99^{a}$ & $12.66^{\mathrm{a}}$ & $13.00^{\mathrm{a}}$ & Maximum at 20 \\
\hline 3. & Ash content & $\%$ & $1.47^{\mathrm{a}}$ & $1.13^{a}$ & $1.57^{\mathrm{a}}$ & $1.43^{\mathrm{a}}$ & Maximum at 2 \\
\hline 4. & Tannin content & $\%$ & $25.14^{\mathrm{a}}$ & $21.9^{\text {a }} 9$ & $23.24^{a}$ & $23.95^{\mathrm{a}}$ & - \\
\hline 5. & Tensile strength & $\mathrm{N} / \mathrm{cm}$ & $354,13^{\mathrm{a}}$ & $350.25^{a}$ & $351.39^{a}$ & $356.35^{\mathrm{a}}$ & Minimum at 300 \\
\hline 6. & Elongation & $\%$ & $28.67^{\mathrm{a}}$ & $27.74^{a}$ & $25.28^{a}$ & $29.80^{a}$ & Maximum at 40 \\
\hline 7. & Sewing strength & $\mathrm{Kg} / \mathrm{cm}$ & $70.19^{a}$ & $69.81^{a}$ & $84.41^{\mathrm{a}}$ & $81.19^{a}$ & Minimum at 50 \\
\hline
\end{tabular}

Note: Different superscript in the same row indicated significant differences $(P<0.05)$ 
The quality of tanned rabbit hide from mangrove tannin extract and mimosa tannin from various ratios was explained as follows:

\section{Chemical Properties (Tanning Degree, Moisture Content, Ash Content and Tannin Content)}

The degree of tanning is the processing level of tanned hide. If tanning degree percentage is high, it is indicated that the hide was perfectly processed and the physical properties were also good. In contrast, the low tanning degree indicated if the hide was not well-processed yet. Table 2 showed that the use of tanned materials with $30 \%$ mimosa tannins or $30 \%$ mangrove tannins gave the same degree of tanning at a significance level of $5 \%$. This indicated that mimosa tannin and mangrove tannin can bind to skin collagen, because the skin contains $\mathrm{C}, \mathrm{H}$, and $\mathrm{O}$. Hydrogen bonds between collagen and tannin also covalent bonds between collagen and tannin make the tanned skin well and evenly processed. Increasing the degree of tanning the hide depends on the amount of tannin that is bound by skin collagen. Thus, the temperature used for tanning rabbit hide from mimosa tannin and mangrove tannin meets SNI 06-6121-1999 by minimum of 25 . It means that the use of mangrove tannin is as good as mimosa tannin, which is probably because the tannin levels from mangroves and from mimosa able to bind perfectly with skin collagen.

Table 2 showed that the water content of tanned hide with mangrove tannin and mimosa tannin produced tanned hide with a lower water content by $13.32 \%$ from the regulation of the SNI 06-6121-1999 standard with maximum water content of $20 \%$. Low water content can also be affected by free water and bound water that comes out because of the olation process. In the tanning process, the olation process occurred, which was a binding between the same two molecules into larger molecules by removing water. The release of free water and water bound to the tanning process can cause the water content in the skin to decrease, so that its amount becomes relatively the same.

The results of ash content in Table 2 showed the highest ash content value was $1.57 \%$, which was still low compared to SNI 06$6121-1999$, which is a maximum of $2.00 \%$. Ash content on tanned hide shows the amount of minerals found in the tanned hide itself. Some mineral elements contained in the tanned hide include potassium, calcium, iron, phosphorus, chloride, sulfate, and carbonate [13]. The low ash content in the tanned skin results showed that the tanning process runs perfectly, so that many minerals dissolved in water. In addition, the deliming process that run well was able to release mineral elements attached to the skin such as Ca.

Bound tannin level is influenced by the amount of tannin that can diffuse into the skin tissue. From Table 2, bound tannin level was ranging from $21.9 \%-25.14 \%$. The highest bound tannin content was obtained by mimosa tannin $30 \%$. From Table 2, it can be seen that the lower the concentration of mimosa tannin material used, the less amount of tannin that could enter the skin tissue, so that the amount of tannin bound by skin collagen was lower. However, the tannin level was high again when using tannin material from mangrove tannin. It indicated that mangroves and mimosa are condensing tannin groups. Condensed tannins are preferred for tanning processes compared to hydrolyzed tannin because they have a higher affinity to collagen tissue because of their high molecular weight and the number of phenolic groups which give many points to the bonds that occur with carbonyl groups from peptides [14].

\section{Physical Properties (Tensile Strength Elonga- tion and Sewing Strength)}

The highest tensile strength was obtained in tanning with mangrove tannin $30 \%$ at 356.35 $\mathrm{N} / \mathrm{cm}$ and the lowest was in the mangrove: mimosa $10 \%: 20 \%=350.25 \mathrm{~N} / \mathrm{cm}$ ratio. However, all treatments of the research results were stated to meet SNI $06-6121-1999$ concerning leather goods which required a minimum tear strength of $300 \mathrm{~N} / \mathrm{cm}$. This shows that the tensile strength values in all treatments met the consumer acceptance standards. The results of tanned rabbit hide with mimosa tannin and mangrove tannin showed that it could be used as accessories in the leather goods manufacture. Tanned rabbit hide which meet the consumer acceptance standard of tensile strength according will be more durable, so that when it is used to make leather shoe product, it can provide consumer comfort in its use. 
The elongation percentage of the hide tested showed the elasticity of the hide. The high elongated leather allows the leather to not be easily torn or damaged during its use [13]. In Table 2, it can be seen that the highest elongation was $29.80 \%$ in tanned skin with $30 \%$ mangrove tannin. While the lowest elongation was $27.74 \%$ in tanned skin with a mangrove tannin ratio of $10 \%$ : mimosa $20 \%$. Extensions for all treatments met the requirements of SNI 06$6121-1999$, which require a maximum of $55 \%$. It means that the elongation value of rabbit hide in all treatments met the consumer acceptance standard (maximum 40\%). The higher the value of the stretched skin (close to and or higher than the standard value), it will produce an unstable product (changes in shape and size) so it is not comfortable to wear. Skin elongation has a major influence on the product, for example if elongation value is very low, then when the product (shoes) are woven with a machine then the skin will break or crack. On the contrary, too high elongation results in shoes getting bigger and changing shape during use because the skin has increased length. In general, limp leather has a high tensile strength, so that when receiving maximum traction force until breaking, it will be more elastic and provide greater length increase.

Sewing strength is one of the physical strength parameters of the tanned hide. The sewing strength will be different if the thickness of the hide is different. It is because the thickness of the hide is a numerator in the calculation of the sewing strength test. The thicker the hide, the smaller the value of the sewing strength. Conversely, the thinner the hide, the greater the value of the sewing strength. In Table 2 , it can be seen that the highest sewing strength was 84.41 $\mathrm{kg} / \mathrm{cm}$ by using a ratio between mangrove and mimosa tannin by $20 \%: 10 \%$. While the lowest sewing strength was $69.81 \mathrm{~kg} / \mathrm{cm}$ by using a ratio between mangrove and mimosa tannin by $10 \%: 20 \%$. However, the tensile strength for all treatments fulfilled the requirements of SNI 06-6121-1999, which requires a minimum of 50 $\mathrm{kg} / \mathrm{cm}$. Tannin which is bound by the leather in the tanning process will coat the collagen fibers that are exposed during the calcification process, so that the fibers will become stronger. It is the cause of the good sewing strength in this study.

\section{CONCLUSION}

The conclusion of this research is the tannin extract from mangrove stems can be used as a tanned material (vegetable) for rabbit skin because its quality is as good as the rabbit skin tanned with mimosa tannin extract.

\section{Acknowledgements}

The gratitude is delivered to Directorate of Research and Community Service University of Muhammadiyah Malang, which gave us the opportunity to do this research.

\section{REFERENCES}

1. Anggriyani, E., Nugroho, A.R., Rosiati, N.M., Technology of Reducing $\mathrm{Cr}(\mathrm{VI})$ on Leather Processing Using Mimosa As Retanning Agent, Leather and Footwear Journal, 2019, 19, 1, 67-72, https://doi.org/10.24264/Ifj.19.1.8.

2. Sutyasmi, S., Widowati, T.P., Setyadewi, N.M., The effect of mimosa in the tanning of vegetable-tanned sheep leather for jackets using C-RFP system on the organoleptic, physical, and morphology properties of leather, Manjalah Kulit, Karet, dan Plastic, 2016, 32, 1, 31-38.

3. Kasim, A., Nurdin, H., Mutiar, S., Aplikasi gambir sebagai bahan penyamak kulit melalui penerapan penyamakan kombinasi, Jurnal Litbang Industri, 2012, 2, 2, 55-62.

4. Musa, A.E., Gasmelseed, G.A., Semi-chrome upper leather from rural goat vegetable tanned crust, Journal of Applied and Industrial Sciences, 2013, 1, 1, 43-48.

5. Yogananth, N., Anuradha, V., Syed Ali, M.Y., Muthezhilan, R., Chanthuru, A., Prabu, M.M., Chemical properties of essential oil from Rhizophora mucronata mangroveleaf against malarial mosquito Anopheles stephensi and filarial mosquito Culex quinquefasciatus, Asian Pac J Trop Dis, 2015, Suppl 1, S67-S72.

6. Punrattanasin, N., Nakpathom, M., Somboon, B., Narumol, N., Rungruangkitkrai, 
N., Mongkholrattanasit, R., Silk fabric dyeing with natural dye from mangrove bark (Rhizophora apiculata Blume) extract, Ind Crop Prod, 2013, 49, 122-129.

7. Pringgenies, D., Supriyantini, E., Azizah, R., Hartati, R., Irwani dan Radjasa, O.K., Aplikasi Pewarnaan Bahan Alam Mangrove Untuk Bahan Batik Sebagai Diversifikasi Usaha Di Desa Binaan Kabupaten Semarang, Jurusan IImu Kelautan \& MSDP, FPIK Universitas Diponegoro, Semarang, 2012.

8. Rusila, N.Y., Khazali, M., Suryadipura, I., Panduan Pengenalan Mangrove di Indonesia, Bogor, Indonesia, Ditjen PHKA dan Wetlands International Indonesia Programme, 2012.

9. Zhang, L., Wang, Y., Wu, D., Xu, M., Chen, J., Study on the Structure of Mangrove Polyflavonoid Tannins with Maldi-TOF Mass Spectrometry and NMR, Adv Mater Res, 2012, Vol 554-556, 1988-1993, https://doi. org/10.4028/www.scientific.net/AMR.554556.1988.

10. Kasmudjiastuti, E., Sutyasmi, S., Widowati, T.P., Pemanfaatan tanin dari kulit kayu tingi (Ceriops tagal) sebagai bahan penyamak nabati: Pengaruh penambahan alum dan mimosa, Manjalah Kulit, Karet, dan Plastic, 2015, 31, 1, 45-54.
11. Paridah, M.T., Musgrave, O.C., Alkaline Treatment of Sulfited Tannin-Based Adhesive from Mangrove to Increase Bond Integrity of Beech Slips, J Trop For Sci, 2006, 18, 2, 137143.

12. Castell, J.C., Fabregat, C., Sorolla, S., Solano, D., Olle, L.L., Bacardit, A., Optimizing a Sustainable and Innovative Wet White Process with Tara Tanins, J Am Leather Chem As, 2011, 106, 278-286.

13. Suparno, O., Kartika, I.A., Mubarak, S., An innovative new application of oxidizing agent to accelerate chamois leather tanning: Part I: the effects of oxidizing agents on chamois leather quality, J Am Leather Chem As, 2011, 106, 12, 360-366.

14. Sexena, M., Sexena, J., Rajeev, N., Singh, D., Gupta A., Phytochemistry of Medicinal Plants, J Pharmacogn Phytochem, 2013, 1, 168-182.

(C) 2019 by the author(s). Published by INCDTP-ICPI, Bucharest, RO. This is an open access article distributed under the terms and conditions of the Creative Commons Attribution license (http://creativecommons.org/licenses/ by/4.0/). 